\title{
EFFECT OF PSYCHO-YOGIC TRAINING INTERVENTION ON SELECTED PSYCHOLOGICAL VARIABLES OF FEMALE POLICE RECRUITS
}

\author{
Tanvi Singh ${ }^{1 \mathrm{ABCD}}$, Gaurav S. Kushwah ${ }^{1 \mathrm{ABCD}}$, Gaurav Singh ${ }^{1 \mathrm{BC}}$, Rohit K. Thapa ${ }^{1 \mathrm{CD}}$ \\ ${ }^{1}$ Rashtriya Raksha University \\ Authors' Contribution: A - Study design; B - Data collection; C - Statistical analysis; D - Manuscript Preparation; E - Funds Collection
}

Corresponding Author: Rohit K. Thapa, E-mail: rohitkumar.thapa@rru.ac.in

Accepted for Publication: October 29, 2021

Published: December 25, 2021

DOI: 10.17309/tmfv.2021.4.07

\begin{abstract}
The purpose of this study was to find the effects of an eight-week psycho-yogic training intervention on the selected psychological parameters of female police recruits.

Materials and methods. Initially, the study involved 200 female police recruits. Out of the 200 participants, 100 participants were screened using the lie score of the revised Eysenck Personality Questionnaire. Participants were then further divided into two groups (i.e., experimental and control) using the stratified random sampling method based on the lie score. The psychological variables selected for the study were aggression (physical aggression, verbal aggression, hostility, and anger), emotional intelligence (self-awareness, managing emotions, self-motivation, empathy, and social skill), anxiety, perceived stress, satisfaction with life, and self-esteem. Tests were conducted pretraining and post-training after eight weeks.

Results. The Friedman's two-way analysis of variance revealed significant difference in verbal aggression $(p=0.016)$, hostility $(\mathrm{p}=0.017)$, managing emotions $(\mathrm{p}=0.004)$, self-motivation $(\mathrm{p}=0.004)$, empathy $(\mathrm{p}=0.017)$, social skill $(\mathrm{p}=0.015)$, anxiety $(\mathrm{p}=<0.001)$, perceived stress $(\mathrm{p}=<0.001)$, satisfaction with life $(\mathrm{p}=0.022)$, and self-esteem $(\mathrm{p}=<0.001)$. Further post-hoc analysis test - Kruskal Wallis revealed that the experimental group improved significantly from pre- to post-test in managing emotions $(\mathrm{p}=0.005, \mathrm{~d}=0.61, \Delta \%=9)$, self-motivation $(\mathrm{p}=0.027$, $\mathrm{d}=0.57, \Delta \%=8.8)$, social skill $(\mathrm{p}=0.002, \mathrm{~d}=0.59, \Delta \%=10.2)$, satisfaction with life $(\mathrm{p}=0.036, \mathrm{~d}=0.5, \Delta \%=11.7)$, and self-esteem $(\mathrm{p}=<0.001, \mathrm{~d}=0.94, \Delta \%=17.6)$. In addition, the experimental group had reduced anxiety $(\mathrm{p}=<0.001, \mathrm{~d}=1.27, \Delta \%=59.3)$ and perceived stress $(\mathrm{p}=<0.001, \mathrm{~d}=1.32, \Delta \%=41.7)$ from pre- to post-testing. On the other hand, the control group showed significant deterioration in physical aggression $(\mathrm{p}=0.018, \mathrm{~d}=0.58$, $\Delta \%=19.9)$, verbal aggression $(\mathrm{p}=0.017, \mathrm{~d}=0.57, \Delta \%=17)$, and hostility $(\mathrm{p}=0.013, \mathrm{~d}=0.54, \Delta \%=17.8)$.

Conclusion. The study findings suggest psycho-yogic training of eight weeks duration to be an effective strategy or method to improve the psychological parameters of female police recruits.

Keywords: emotional intelligence, anxiety, self-esteem, satisfaction, perceived stress, aggression.
\end{abstract}

\section{Introduction}

Police personnel is supposed to be physically and psychologically strong to meet the occupational demands of their profession. The police personnel are also relatively expected to perform, engage and execute a variety of tasks such as maintaining law and order, dealing with criminals, communal riots, prison, and paroling duties, etc. Therefore, to meet such demands and handle such circumstances to maintain law and order in the society, police personnel develops various psychological issues such as high level of anxiety, stress, aggression and a variety of other stressors, which ultimately makes this profession stressful (Akinlabi, 2021;

(c) Singh, T., Kushwah, G. S., Singh, G., \& Thapa, R. K., 2021.
Anshel, 2000). Prolonged exposure to such psychological situations causes work-life imbalance, emotional imbalance, dissatisfaction with job, depression and sometimes it may also develop suicidal tendencies among police personnel (Akinlabi, 2021).

The magnitude of the stress and its effect on psychological and physical health usually depends on the type of stress (i.e., acute or chronic) (Anderson et al., 2002). The acute stress may be due to sudden and critical incidents, which require immediate response (Evans et al., 1993; Katarina Ahlstrom, 1993). Whereas, chronic stress is the prolonged phase of a stressor which are built over a period of time (Anshel, 2000). These conditions are an inseparable part of the occupation of the police personnel and are very much psychologically challenging. 
Previous studies have reported that police personnel are on the higher risk end and suffers from a high level of anxiety, stress, depression, and emotional imbalance state, which may ultimately reduce their productivity in the long run (Agrawal \& Mahajan, 2021; Bora et al., 2021; Mann, 2021; Singh et al., 2021). The newly recruited police personnel have to undergo physical training which includes various indoor and outdoor activities.

Psychological training which includes both mind and body has been reported to decrease perceived stress, improves mood and other psychological measures (Abhaydev et al., 2020; Jung et al., 2016; Lane et al., 2007). Yoga-based lifestyle interventions have reportedly been shown to reduce stress (Greeson et al., 2015) and anxiety (Gupta et al., 2006). In addition, various psychological training programs (e.g., mindfulness-based stress reduction and healing arts programs) have reported significant effects on factors such as anxiety, anger, mood disturbances, and overall stress symptoms (Garland et al., 2007). Furthermore, reduction in stress level, improvement in coping and mindfulness have been reported using integrative coping and resiliency programs (Deible et al., 2015; Tarantino et al., 2013).

It has been found that very little or no attention is given to include the self-regulatory psychological and yogic training which is helpful to resolve the psychological challenges; anxiety, stress, anger, loss of energy emotion regulation, associated with their profession (Blumberg et al., 2022; Wang $\& \mathrm{Liu}, 2022)$. It was also noticed that the responses of male and female police personnel were different to stressful and workplace situations (Jha, 2020). Hence, the joint protocol (psychological interventions and yoga practices) was introduced to test the effectiveness of Psycho-Yogic intervention on female police recruits (FPR).

\section{Materials and methods}

\section{Study participants}

A total of 200 new female recruits of constable level were initially selected from a police training centre of Gujarat, India. Thereafter the selected participants were asked to fill up the revised Eysenck Personality Questionnaire (Eysenck et al., 1985). A total of 198 participants correctly filled the questionnaire and the responses of two participants were discarded due to incomplete responses. Lie scores were calculated for each subject using the revised Eysenck Personality Questionnaire. Later, the best 100 participants

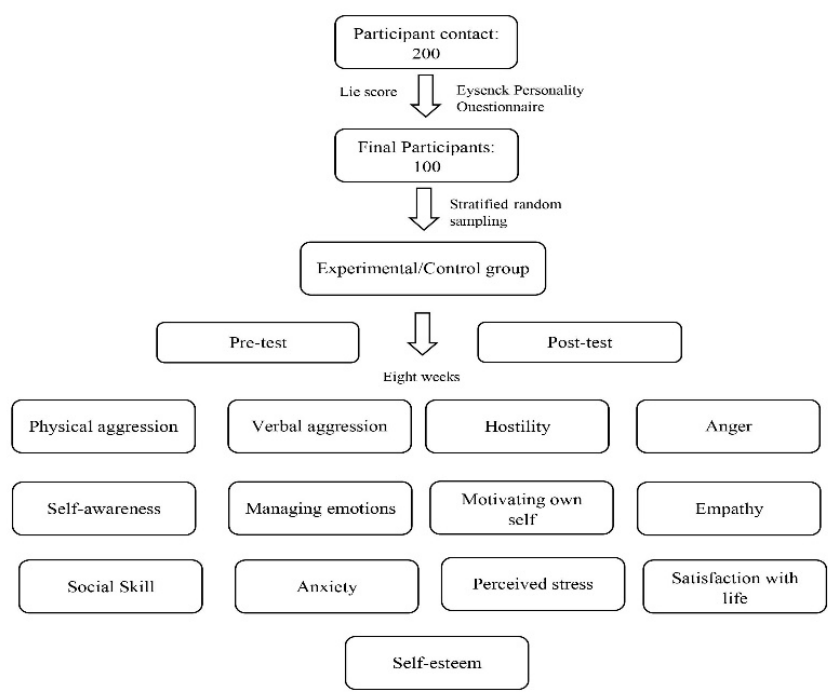

Fig. 1. Graphical representation of the study.

Table 1. Brief description of the psycho-yogic protocols included in this study

\begin{tabular}{|c|c|c|c|}
\hline S1. No. & Main Activity & Sub-activity & Benefits \\
\hline 1 & Psychological Skill Training & $\begin{array}{l}\text { Goal Setting } \\
\text { Self - Talk } \\
\text { Mental Imagery } \\
\text { Mental Rehearsal } \\
\text { Relaxation }\end{array}$ & $\begin{array}{l}\text { PST methods have all been proven to improve psychological } \\
\text { skills like self-confidence, control activation, arousal, stress, } \\
\text { cognitive process. }\end{array}$ \\
\hline 2 & Pranayama & $\begin{array}{l}\text { Bhramri } \\
\text { Nadishodhan } \\
\text { Sahit kumbhak } \\
\text { Shitali Pranayama }\end{array}$ & $\begin{array}{l}\text { It is reported to reduce stress and anxiety, improves autonomic } \\
\text { functions by triggering neurohormonal mechanisms by the } \\
\text { suppression of sympathetic activity. }\end{array}$ \\
\hline 3 & Sudarshan Kriya & $\begin{array}{l}\text { Ujjayi } \\
\text { Bhastrika } \\
\text { Om Chanting } \\
\text { Kriya (Breathing) }\end{array}$ & $\begin{array}{l}\text { Alleviate anxiety, depression, everyday stress, post-traumatic } \\
\text { stress, and stress-related medical illnesses. Mechanisms } \\
\text { contributing to a state of calm alertness include increased } \\
\text { parasympathetic drive, calming of the stress response systems. }\end{array}$ \\
\hline 4 & Stretching & $\begin{array}{l}\text { Shasangasana } \\
\text { Bhujangasana } \\
\text { Setubandhasan } \\
\text { Pwanmuktasana } \\
\text { Pacchimottanasan }\end{array}$ & $\begin{array}{l}\text { Stretching helps improve your range of motion, which may also } \\
\text { slow the degeneration of your joints. Stretching major muscles } \\
\text { helps keep them loose and lessens the shortening and tightening } \\
\text { effect that can lead to post-workout aches and pains. }\end{array}$ \\
\hline
\end{tabular}


Table 2. Description of all the psychological tests included in the study

\begin{tabular}{|c|c|c|c|}
\hline Sl. No. & Variables & Tool & Scoring \\
\hline 1 & Aggression & $\begin{array}{l}\text { Aggression Questionnaire } \\
\text { (Buss \& Perry, 1992) }\end{array}$ & Sum of the Factor Scores \\
\hline 2 & Anxiety & $\begin{array}{l}\text { GAD } 7 \text { Anxiety Scale } \\
\text { (Spitzer et al., 2006) }\end{array}$ & $\begin{array}{l}15-21=\text { Severe Anxiety } \\
10-14=\text { Moderate Anxiety } \\
\text { 5-9 = Mild Anxiety } \\
0-4=\text { Minimal Anxiety }\end{array}$ \\
\hline 3 & Emotional Intelligence & $\begin{array}{l}\text { Emotional Intelligence Questionnaire } \\
\text { (Leadership toolkit, (EI) Emotional Intelligence } \\
\text { Questionnaire) }\end{array}$ & $\begin{array}{l}35-50=\text { Strength } \\
18-34=\text { Giving Attention } \\
10-17=\text { Development Priority }\end{array}$ \\
\hline 4 & Stress & $\begin{array}{l}\text { Perceived Stress Scale } \\
\text { (Cohen et al., 1983) }\end{array}$ & $\begin{array}{l}27-40=\text { High Perceived Stress } \\
14-26=\text { Medium Perceived Stress } \\
0-13=\text { Low Perceived Stress }\end{array}$ \\
\hline 5 & Satisfaction with life & $\begin{array}{l}\text { Satisfaction with Life Scale } \\
\text { (Diener et al., 1985) }\end{array}$ & $\begin{array}{l}31-35=\text { Extremely Satisfied } \\
26-30=\text { Satisfied } \\
21-25=\text { Slightly Satisfied } \\
20=\text { Neutral } \\
15-19=\text { Slightly Dissatisfied } \\
10-14=\text { Dissatisfied } \\
5-9=\text { Extremely Dissatisfied }\end{array}$ \\
\hline 6 & Self-esteem & $\begin{array}{l}\text { Rosenberg Self-esteem Scale } \\
\text { (Rosenberg, 2015) }\end{array}$ & Higher Score Indicates Higher Self-esteem \\
\hline
\end{tabular}

with a low lie score threshold of $\leq 14$ were selected for the study. Further, the subjects were stratified into five classifications based on the lie scores (e.g., 1-3, 4-6, 7-9, 10-12, and 13-14) and lastly, assigned into two groups (i.e., experimental group and control group) using the stratified random sampling.

\section{Study organization}

Pre-test - post-test experimental group design was used for the study. The experimental group was subjected to a list of psycho-yogic activities which they performed 3 sessions/ week (Table 1). The duration of the study was eight weeks, with the first week focused on the familiarization session (Education phase) followed by seven weeks of training (e.g., acquisition phase, practice phase I, practice phase II). The training sessions lasted between 45 minutes to 60 minutes duration. The data were collected for selected psychological variables using questionnaires (Table 2).

\section{Statistical analyses}

Data are presented as mean and standard deviation (SD). The Shapiro-Wilk test revealed that the assumptions of normality were violated and the data were not normal. Therefore, a non-parametric test (i.e., Friedman's two-way analysis of variance) equivalent to its parametric counterpart was used for analysis. Friedman's two-way analysis of variance was used to determine the effect of training on the groups. Further, the post-hoc analyses were conducted using the Kruskal Wallis test (non-parametric) to determine the pre- post-effect in both groups (i.e., experimental group and control group). Percentage change was also calculated for both experimental and control groups using the equation: [(Meanpost-Meanpre)/Meanpre] $\times 100$. Effect sizes were calculated using Cohen's $d$ to assess changes between pre- to post- measurements in each group. The magnitude of effects for Cohen's d was interpreted as trivial $(<0.2)$, small $(0.2-0.6)$, moderate $(>0.6-1.2)$, large $(>1.2-2.0)$, very large (>2.0-4.0), and extremely large (>4.0) (Hopkins et al., 2009). Statistical significance was set at $\mathrm{p} \leq 0.05$.

\section{Results}

The mean $[\mathrm{SD}]$ for each dependent variable is shown in Table 3. Statistical outcomes for comparisons in each dependent variable are also shown in Table 3. Friedman's two-way analysis of variance revealed significant difference among experimental and control after eight weeks of training program in verbal aggression $(\mathrm{p}=0.016)$, hostility $(\mathrm{p}=0.017)$, managing emotions $(p=0.004)$, motivating own self $(p=0.004)$, empathy $(\mathrm{p}=0.017)$, social skill $(\mathrm{p}=0.015)$, anxiety $(\mathrm{p}=<0.001)$, perceived stress $(p=<0.001)$, satisfaction with life $(p=0.022)$, and self-esteem ( $\mathrm{p}=<0.001)$ (Table 3$)$. No significant differences were observed in physical aggression $(\mathrm{p}=0.287)$, anger $(\mathrm{p}=0.135)$, and self-awareness $(\mathrm{p}=0.20)$.

Further post-hoc analysis using the Kruskal Wallis test revealed experimental group improved significantly from pre- to post-test in managing emotion $(\mathrm{p}=0.005, \mathrm{~d}=0.61, \Delta \%=9)$, motivating own self ( $\mathrm{p}=0.027, \mathrm{~d}=0.57, \Delta \%=8.8$ ), social skill ( $\mathrm{p}=0.002, \mathrm{~d}=0.59, \Delta \%=10.2)$, satisfaction with life $(\mathrm{p}=0.036, \mathrm{~d}=0.5, \Delta \%=11.7)$, and self-esteem $(\mathrm{p}=<0.001$, $\mathrm{d}=0.94, \Delta \%=17.6)$. In addition, the experimental group had also showed reduction in the anxiety level $(\mathrm{p}=<0.001$, $\mathrm{d}=1.27, \Delta \%=59.3)$ and perceived stress $(\mathrm{p}=<0.001, \mathrm{~d}=1.32$, $\Delta \%=41.7)$ from pre- to post-test. While the control group showed significant deterioration in physical aggression $(\mathrm{p}=0.018, \mathrm{~d}=0.58, \Delta \%=19.9)$, verbal aggression $(\mathrm{p}=0.017$, $\mathrm{d}=0.57, \Delta \%=17)$, and hostility $(\mathrm{p}=0.013, \mathrm{~d}=0.54, \Delta \%=17.8)$. 
Table 3. Descriptive and inferential statistics of the data

\begin{tabular}{|c|c|c|c|c|c|c|c|c|c|c|c|c|}
\hline & \multirow{3}{*}{ Variables } & \multicolumn{5}{|c|}{ Experimental Group } & \multicolumn{5}{|c|}{ Control Group } & \multirow{3}{*}{$\begin{array}{c}\text { Friedman's } \\
\text { Two-way } \\
\text { ANOVA } \\
\text { p-value }\end{array}$} \\
\hline & & & & \multirow[b]{2}{*}{$\begin{array}{l}\text { Pre-Post } \\
\text { p-value }\end{array}$} & \multirow[b]{2}{*}{$\begin{array}{c}\text { Pre-Post } \\
\Delta \%\end{array}$} & \multirow[b]{2}{*}{$\begin{array}{l}\text { Pre-Post } \\
\text { (ES) }\end{array}$} & & & \multirow{2}{*}{$\begin{array}{c}\text { Pre- } \\
\text { Post } \\
\text { p-value }\end{array}$} & \multirow{2}{*}{$\begin{array}{c}\text { Pre-Post } \\
\Delta \%\end{array}$} & \multirow[b]{2}{*}{$\begin{array}{l}\text { Pre-Post } \\
\text { (ES) }\end{array}$} & \\
\hline & & \multicolumn{2}{|c|}{ Mean [SD] } & & & & Mean & [SD] & & & & \\
\hline \multirow{4}{*}{ 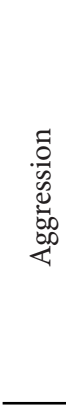 } & Physical Aggression & $\begin{array}{l}21.92 \\
{[6.45]}\end{array}$ & $\begin{array}{l}22.30 \\
{[6.24]}\end{array}$ & 0.714 & 1.8 & 0.06 & $\begin{array}{l}19.76 \\
{[5.34]}\end{array}$ & $\begin{array}{c}23.7 \\
{[7.93]}\end{array}$ & 0.018 & 19.9 & 0.58 & 0.287 \\
\hline & $\begin{array}{l}\text { Verbal } \\
\text { Aggression }\end{array}$ & $\begin{array}{l}17.42 \\
{[6.61]}\end{array}$ & $\begin{array}{l}16.12 \\
{[4.04]}\end{array}$ & 0.615 & 7.5 & 0.24 & $\begin{array}{l}14.12 \\
{[3.99]}\end{array}$ & $\begin{array}{l}16.52 \\
{[4.48]}\end{array}$ & 0.017 & 17.0 & 0.57 & 0.015 \\
\hline & Hostility & $\begin{array}{c}22.1 \\
{[7.09]}\end{array}$ & $\begin{array}{l}22.8 \\
{[5.97]}\end{array}$ & 0.727 & 3.2 & 0.11 & $\begin{array}{c}20.2 \\
{[6.25]}\end{array}$ & $\begin{array}{c}23.8 \\
{[7.11]}\end{array}$ & 0.013 & 17.8 & 0.54 & 0.017 \\
\hline & Anger & $\begin{array}{l}20.74 \\
{[5.16]} \\
\end{array}$ & $\begin{array}{l}20.12 \\
{[6.13]}\end{array}$ & 0.582 & 3.0 & 0.11 & $\begin{array}{l}18.06 \\
{[4.12]}\end{array}$ & $\begin{array}{l}19.34 \\
{[5.54]}\end{array}$ & 0.181 & 7.1 & 0.26 & 0.135 \\
\hline \multirow{5}{*}{ 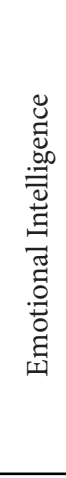 } & Self-Awareness & $\begin{array}{c}40 \\
{[8.57]}\end{array}$ & $\begin{array}{c}43.2 \\
{[4.74]}\end{array}$ & 0.278 & 8.0 & 0.46 & $\begin{array}{c}40.3 \\
{[6.39]}\end{array}$ & $\begin{array}{c}37.9 \\
{[8.30]}\end{array}$ & 0.699 & 6.0 & 0.32 & 0.20 \\
\hline & $\begin{array}{l}\text { Managing } \\
\text { Emotions }\end{array}$ & $\begin{array}{l}34.28 \\
{[6.06]}\end{array}$ & $\begin{array}{l}37.38 \\
{[3.78]}\end{array}$ & 0.005 & 9.0 & 0.61 & $\begin{array}{l}33.76 \\
{[5.63]}\end{array}$ & $\begin{array}{l}33.16 \\
{[5.72]}\end{array}$ & 0.816 & 1.8 & 0.11 & 0.004 \\
\hline & $\begin{array}{l}\text { Motivating Own } \\
\text { self }\end{array}$ & $\begin{array}{c}37.7 \\
{[6.87]}\end{array}$ & $\begin{array}{c}41.0 \\
{[4.38]}\end{array}$ & 0.027 & 8.8 & 0.57 & $\begin{array}{c}37.9 \\
{[5.44]}\end{array}$ & $\begin{array}{c}36.2 \\
{[6.19]}\end{array}$ & 1.31 & 1.7 & 0.29 & 0.004 \\
\hline & Empathy & $\begin{array}{c}38.1 \\
{[6.54]}\end{array}$ & $\begin{array}{c}39.8 \\
{[4.62]}\end{array}$ & 0.081 & 4.5 & 0.3 & $\begin{array}{c}36.4 \\
{[7.22]}\end{array}$ & $\begin{array}{c}35.5 \\
{[6.97]}\end{array}$ & 0.333 & 2.5 & 0.13 & 0.017 \\
\hline & Social Skill & $\begin{array}{l}36.24 \\
{[7.65]}\end{array}$ & $\begin{array}{l}39.94 \\
{[5.82]}\end{array}$ & 0.002 & 10.2 & 0.59 & $\begin{array}{l}38.1 \\
{[5.9]}\end{array}$ & $\begin{array}{l}37.36 \\
{[7.17]}\end{array}$ & 0.727 & 1.9 & 0.11 & 0.015 \\
\hline \multicolumn{2}{|c|}{ Anxiety } & $\begin{array}{c}8.1 \\
{[4.62]}\end{array}$ & $\begin{array}{c}3.3 \\
{[2.69]}\end{array}$ & $<0.001$ & 59.3 & 1.27 & $\begin{array}{c}8.2 \\
{[5.10]}\end{array}$ & $\begin{array}{c}8.1 \\
{[4.28]}\end{array}$ & 0.846 & 1.2 & 0.02 & $<0.001$ \\
\hline \multicolumn{2}{|c|}{ Perceived Stress } & $\begin{array}{l}17.02 \\
{[5.95]}\end{array}$ & $\begin{array}{c}9.92 \\
{[4.73]}\end{array}$ & $<0.001$ & 41.7 & 1.32 & $\begin{array}{l}17.64 \\
{[7.87]}\end{array}$ & $\begin{array}{l}18.30 \\
{[8.05]}\end{array}$ & 0.727 & 3.7 & 0.08 & $<0.001$ \\
\hline \multicolumn{2}{|c|}{ Satisfaction with Life } & $\begin{array}{l}22.08 \\
{[6.23]}\end{array}$ & $\begin{array}{l}24.66 \\
{[3.73]}\end{array}$ & 0.036 & 11.7 & 0.50 & $\begin{array}{l}20.58 \\
{[5.55]}\end{array}$ & $\begin{array}{l}22.74 \\
{[4.82]}\end{array}$ & 0.088 & 10.5 & 0.42 & 0.022 \\
\hline \multicolumn{2}{|c|}{ Self-Esteem } & $\begin{array}{l}18.32 \\
{[4.02]}\end{array}$ & $\begin{array}{l}21.54 \\
{[2.69]}\end{array}$ & $<0.001$ & 17.6 & 0.94 & $\begin{array}{l}17.04 \\
{[4.62]}\end{array}$ & $\begin{array}{c}18.3 \\
{[5.43]}\end{array}$ & 0.462 & 7.4 & 0.25 & $<0.001$ \\
\hline
\end{tabular}

Note: $\Delta \%$ - percentage change; ES - effect size (Cohen's d); SD - standard deviation

\section{Discussion}

The study focused on finding the effects of an eight weeks psycho-yogic training intervention on various psychological variables. The results suggest psycho-yogic training to be an effective strategy or method to significantly improve various psychological variables such as managing emotions, motivating own self, social skills, satisfaction with life, and self-esteem. In addition, this training program also reduced perceived stress and anxiety as well as optimally maintained physical aggression, verbal aggression, and hostility in experimental group as compared to the control group.

The experimental group performed both training for mind and body (psycho-yogic) for eight weeks. Psycho-yogic training improved three (out of five) factors of emotional intelligence (i.e., managing emotions, motivating own self, social skill). Similar findings were reported in a previous study (Jung et al., 2016), where the authors suggested that online mind-body training programs improved the emotional intelligence of participants over a period of eight weeks rather than four weeks of duration. A previous study suggests that emotions are related to respiration (Valderas et al., 2015). Since the psycho-yogic training intervention included deep breathing practices, which may have positive impact on physical aspect as well as helped in providing emotional relaxation. The participants included in this study were FPR, who underwent rigorous training regimes and were subjected to emotional labor. The law enforcement officer requires to show the optimum emotions as they have to deal with the society and they are the medium between the citizens and the government. Therefore, the optimal emotional intelligence is highly required to discharge their duties at its best. Thus, psycho-yogic training for emotional release may have been beneficial for the participants. 
It has been reported that integrative mind and body training shows improvement in attention and self-regulation (Tang, 2011). The author suggested that this may be due to the interaction between the autonomic nervous system (body) and the central nervous system (brain) (Tang, 2011). Similar findings were also observed in the present study, where the stress level reduced and emotional intelligence increased, which may be due to psycho-yogic intervention of eight weeks. This may contribute to the police personnel efficiency for their profession.

The study also reported reduction in perceived stress among the psycho-yogic training group. One of the crucial factors in stress reduction may be due to the increase in the emotional intelligence after eight weeks of intervention. Jung et al. (2016) reported an inverse correlation between emotional intelligence scores and self-reported stress and suggested that an increase in emotional intelligence and decrease in perceived stress may interact synergistically. Jung et al. (2016) also suggested that mind-body training may induce or increase these dynamics among participants. Thus, the finding of our study suggests that psycho-yogic training may be capable of improving the mental well-being of participants, which further will lead them to channelize their cognitive functioning. In addition, studies with similar findings have reported the inverse relationship between stress and emotional intelligence (Hisli Sahin et al., 2009; Walpole et al., 2008) further supporting our study's result.

It is suggested that, emotional intelligence acts as a moderator between stress level and psychological health (Sharma et al., 2016). It is also known that increased emotional capability contributes to the use of adaptive coping strategies when dealing with stress (Por et al., 2011). Therefore, the improved (enhanced) emotional intelligence among participants performing psycho-yogic training intervention may have led to improved self-esteem and satisfaction with life as well as reduced the perceived stress. Another reason for stress reduction in our psycho-yogic participants may be because meditation is suggested to potentially strengthen neuronal circuits and enhance the cognitive reserve capacity (Xiong \& Doraiswamy, 2009), thereby contributing to enhanced brain capacity and plasticity of participant. This may have led to frequent use of adaptive coping strategies thereby reducing the stress among the participants.

The participants in our study showed a reduction in the stress and its associated parameters i.e. aggression and anxiety. A study by Lieberman et al. (2015) has shown that severe stress may induce anger. In our study the psycho-yogic group (Experimental Group) had no significant increase in aggression level after the eight weeks of intervention, which may have been possible due to the significant decrease in the stress level. Further findings in our study also showed that the stress level and aggression level of control group increased, whereas psycho-yogic training of eight weeks duration significantly decreased the stress level and maintained aggression level (physical aggression, verbal aggression, and hostility).

The study also reported a reduction of anxiety levels in the psycho-yogic training group. The previous studies have also reported a negative relationship between emotional intelligence and anxiety (Cejudo et al., 2018; Lu et al., 2010), as well as between stress and anxiety (Juruena et al., 2020). Involvement in the psycho-yogic program may have induced emotional intelligence and decrease perceived stress which directly influenced the anxiety level to get reduced among the recruits. In addition, Yoga practices have also reported to lower salivary cortisol level in females (Chen et al., 2017; Gothe et al., 2016). Higher cortisol level is related to stress, anxiety and depression (van Eck et al., 1996; Walvekar et al., 2015).

\section{Conclusion}

The findings of the study suggest that psycho-yogic intervention of eight weeks duration to be an effective strategy or method to improve the mental wellbeing among the FPR. The training intervention may be put into practice by law enforcement organizations along with the physical training program for recruits to overcome the psychological pressure and improve their overall mental wellbeing. The physical training program of recruits has been shown to increase aggression level and therefore the authors suggest psychoyogic intervention to be an effective measure to control it.

\section{Conflict of interest}

The authors declare that there is no conflict of interest.

\section{References}

Akinlabi, O. M. (2021). Evaluating the Predictors of Stress among Police Officers: A Current Psychosocial Analysis from Nigeria. In H. C. Chan \& S. Adjorlolo (Eds.), Crime, Mental Health and the Criminal Justice System in Africa: A Psycho-Criminological Perspective (pp. 259-282). Springer International Publishing. https://doi.org/10.1007/978-3-030-71024-8_12

Anshel, M. H. (2000). A conceptual model and implications for coping with stressful events in police work. Criminal justice and Behavior, 27(3), 375-400.

Anderson, G. S., Litzenberger, R., \& Plecas, D. (2002). Physical evidence of police officer stress. Policing: An International Journal of Police Strategies \& Management, 25(2), 399420. https://doi.org/10.1108/13639510210429437

Evans, B. J., Coman, G. J., Stanley, R. O., \& Burrows, G. D. (1993). Police officers' coping strategies: An Australian police survey. Stress Medicine, 9(4), 237-246. https://doi.org/10.1002/smi.2460090406

Katarina Ahlstrom, M. (1993). Police Stress: A Literature Study on Police Occupational Stressors and the Responses in Police Officers to Stressful Job Events. [Portland State University].

Agrawal, M., \& Mahajan, R. (2021). The effect of optimism on the work-family interface and psychological health of Indian police. Policing: An International Journal, 44(5), 725-740. https://doi.org/10.1108/PIJPSM-10-2020-0161

Bora, S., Chatterjee, A., \& Chakrabarti, D. (2021). A Scrutiny of On-Job Stress and Occupational Well-Being of Indian Policewomen Compared to Chinese Policewomen. In M. Muzammil, A. A. Khan, \& F. Hasan, Ergonomics for Improved Productivity Singapore.

Mann, S. (2021). Factors Affecting Police Stress: A Study of Maharashtra Pol, 2Dr. Surya Rashmi Rawat, ice. Turkish Journal of Computer and Mathematics Education (TURCOMAT), 12(4), 1110-1116.

Singh, S., Gupta, B., \& Mishra, P. C. (2021). Coping strategies and social support as moderators of occupational 
stress and mental health link among police personnel. Industrial psychiatry journal, 30(1), 67-73.

https://doi.org/10.4103/ipj.ipj_207_20

Abhaydev, C. S., Bhukar, J., \& Thapa, R. K. (2020). Effects of IAAF kid's athletics programme on psychological and motor abilities of sedentary school going children. Teoriâ ta Metodika Fizičnogo Vihovannâ, 20(4), 234-241. https://doi.org/10.17309/tmfv.2020.4.06

Jung, Y. H., Ha, T. M., Oh, C. Y., Lee, U. S., Jang, J. H., Kim, J., Park, J. O., \& Kang, D. H. (2016). The Effects of an Online Mind-Body Training Program on Stress, Coping Strategies, Emotional Intelligence, Resilience and Psychological State. PLoS One, 11(8), e0159841. https://doi.org/10.1371/journal.pone.0159841

Lane, J. D., Seskevich, J. E., \& Pieper, C. F. (2007). Brief meditation training can improve perceived stress and negative mood. Altern Ther Health Med, 13(1), 38-44.

Greeson, J. M., Toohey, M. J., \& Pearce, M. J. (2015). An Adapted, Four-Week Mind-Body Skills Group for Medical Students: Reducing Stress, Increasing Mindfulness, and Enhancing Self-Care. EXPLORE, 11(3), 186-192. https://doi.org/10.1016/j.explore.2015.02.003

Gupta, N., Khera, S., Vempati, R. P., Sharma, R., \& Bijlani, R. L. (2006). Effect of yoga based lifestyle intervention on state and trait anxiety. Indian J Physiol Pharmacol, 50(1), 41-47.

Garland, S. N., Carlson, L. E., Cook, S., Lansdell, L., \& Speca, M. (2007). A non-randomized comparison of mindfulnessbased stress reduction and healing arts programs for facilitating post-traumatic growth and spirituality in cancer outpatients. Support Care Cancer, 15(8), 949-961. https://doi.org/10.1007/s00520-007-0280-5

Deible, S., Fioravanti, M., Tarantino, B., \& Cohen, S. (2015). Implementation of an integrative coping and resiliency program for nurses. Glob Adv Health Med, 4(1), 28-33. https://doi.org/10.7453/gahmj.2014.057

Tarantino, B., Earley, M., Audia, D., D’Adamo, C., \& Berman, B. (2013). Qualitative and Quantitative Evaluation of a Pilot Integrative Coping and Resiliency Program for Healthcare Professionals. EXPLORE, 9(1), 44-47. https://doi.org/10.1016/j.explore.2012.10.002

Blumberg, D. M., Papazoglou, K., Creighton, S., \& Kaye, C. (2022). Chapter 3 - Incorporating psychological skills in police academy training. In P. B. Marques \& M. Paulino (Eds.), Police Psychology (pp. 47-62). Academic Press. https://doi.org/10.1016/B978-0-12-816544-7.00003-6

Wang, S., \& Liu, Y. (2022). Analysis of the Intervention of Yoga on Emotion Regulation Based on Big Data. In B. J. Jansen, H. Liang, \& J. Ye, International Conference on Cognitive based Information Processing and Applications (CIPA 2021) Singapore.

Jha, N. K. (2020). Ways of Coping and Mental Health among Male and Female Police Constables: A Comparative Study. The Indian Police Journal, 159.

Eysenck, S. B. G., Eysenck, H. J., \& Barrett, P. (1985). A revised version of the psychoticism scale. Personality and Individual Differences, 6(1), 21-29. https://doi.org/10.1016/0191-8869(85)90026-1

Buss, A. H., \& Perry, M. (1992). The aggression questionnaire. Journal of personality and social psychology, 63(3), 452.

Spitzer, R. L., Kroenke, K., Williams, J. B., \& Löwe, B. (2006). A brief measure for assessing generalized anxiety disorder: the GAD-7. Archives of internal medicine, 166(10), 1092-1097.

Leadership toolkit, (EI) Emotional Intelligence Questionnaire. https://www.drugsandalcohol.ie/26776/1/Emotional_ intelligence_questionnaire-LAL1.pdf
Cohen, S., Kamarck, T., \& Mermelstein, R. (1983). A global measure of perceived stress. Journal of health and social behavior, 385-396.

Diener, E., Emmons, R. A., Larsen, R. J., \& Griffin, S. (1985). The satisfaction with life scale. Journal of personality assessment, 49(1), 71-75.

Rosenberg, M. (2015). Society and the adolescent self-image. Princeton university press.

Hopkins, W. G., Marshall, S. W., Batterham, A. M., \& Hanin, J. (2009). Progressive statistics for studies in sports medicine and exercise science. Med Sci Sports Exerc, 41(1), 3-13. https://doi.org/10.1249/MSS.0b013e31818cb278

Valderas, M. T., Bolea, J., Laguna, P., Vallverdú, M., \& Bailón, R. (2015). Human emotion recognition using heart rate variability analysis with spectral bands based on respiration. Annu Int Conf IEEE Eng Med Biol Soc, 2015, 6134-6137. https://doi.org/10.1109/embc.2015.7319792

Tang, Y. Y. (2011). Mechanism of integrative body-mind training. Neurosci Bull, 27(6), 383-388. https://doi.org/10.1007/s12264-011-1141-2

Hisli Sahin, N., Güler, M., \& Basim, H. N. (2009). [The relationship between cognitive intelligence, emotional intelligence, coping and stress symptoms in the context of type A personality pattern]. Turk Psikiyatri Derg, 20(3), 243-254. (A Tipi Kişilik Orüntüsünde Bilişsel ve Duygusal Zekânin Stresle Başa Cikma ve Stres Belirtileri ile Ilişkisi.)

Walpole, P., Isaac, C. L., \& Reynders, H. J. (2008). A comparison of emotional and cognitive intelligence in people with and without temporal lobe epilepsy. Epilepsia, 49(8), 14701474. https://doi.org/10.1111/j.1528-1167.2008.01655.x

Sharma, J., Dhar, R. L., \& Tyagi, A. (2016). Stress as a mediator between work-family conflict and psychological health among the nursing staff: Moderating role of emotional intelligence. Applied Nursing Research, 30, 268-275. https://doi.org/10.1016/j.apnr.2015.01.010

Por, J., Barriball, L., Fitzpatrick, J., \& Roberts, J. (2011). Emotional intelligence: its relationship to stress, coping, well-being and professional performance in nursing students. Nurse Educ Today, 31(8), 855-860. https://doi.org/10.1016/j.nedt.2010.12.023

Xiong, G. L., \& Doraiswamy, P. M. (2009). Does meditation enhance cognition and brain plasticity? Ann N Y Acad Sci, 1172, 63-69. https://doi.org/10.1196/annals.1393.002

Lieberman, H. R., Thompson, L. A., Caruso, C. M., Niro, P. J., Mahoney, C. R., McClung, J. P., \& Caron, G. R. (2015). The catecholamine neurotransmitter precursor tyrosine increases anger during exposure to severe psychological stress. Psychopharmacology, 232(5), 943-951. https://doi.org/10.1007/s00213-014-3727-7

Cejudo, J., Rodrigo-Ruiz, D., López-Delgado, M. L., \& Losada, L. (2018). Emotional Intelligence and Its Relationship with Levels of Social Anxiety and Stress in Adolescents. Int J Environ Res Public Health, 15(6). https://doi.org/10.3390/ijerph15061073

Lu, F. J., Li, G. S., Hsu, E. Y., \& Williams, L. (2010). Relationship between athletes' emotional intelligence and precompetitive anxiety. Percept Mot Skills, 110(1), 323338. https://doi.org/10.2466/pms.110.1.323-338

Juruena, M. F., Eror, F., Cleare, A. J., \& Young, A. H. (2020). The Role of Early Life Stress in HPA Axis and Anxiety. Adv Exp Med Biol, 1191, 141-153. https://doi.org/10.1007/978-981-32-9705-0_9

Chen, P. J., Yang, L., Chou, C. C., Li, C. C., Chang, Y. C., \& Liaw, J. J. (2017). Effects of prenatal yoga on women's stress and immune function across pregnancy: A 
randomized controlled trial. Complement Ther Med, 31, 109-117. https://doi.org/10.1016/j.ctim.2017.03.003

Gothe, N. P., Keswani, R. K., \& McAuley, E. (2016). Yoga practice improves executive function by attenuating stress levels. Biol Psychol, 121(Pt A), 109-116. https://doi.org/10.1016/j.biopsycho.2016.10.010

van Eck, M., Berkhof, H., Nicolson, N., \& Sulon, J. (1996).

The Effects of Perceived Stress, Traits, Mood States, and
Stressful Daily Events on Salivary Cortisol. Psychosomatic Medicine, 58(5), 447-458.

Walvekar, S. S., Ambekar, J. G., \& Devaranavadagi, B. B. (2015). Study on serum cortisol and perceived stress scale in the police constables. Journal of clinical and diagnostic research: JCDR, 9(2), BC10-BC14. https://doi.org/10.7860/JCDR/2015/12015.5576

\title{
ВПЛИВ ПСИХО-ЙОГІЧНОГО ТРЕНУВАННЯ НА ВИБРАНІ ПСИХОЛОГІЧНІ ЗМІННІ ЖІНОК-НОВОБРАНЦІВ ПОЛІЦІї
}

\author{
Танві Сінгх ${ }^{1 \mathrm{ABCD}}$, Гаурав С. Кушва ${ }^{1 \mathrm{ABCD}}$, Гаурав Сінгх ${ }^{1 B C}$, Рохіт К. Тапа ${ }^{1 \mathrm{CD}}$ \\ ${ }^{1}$ Університет Раштрія Ракша
}

Авторський вклад: А - дизайн дослідження; В - збір даних; C - статаналіз; D - підготовка рукопису; Е - збір коштів

Реферат. Стаття: 7 с., 5 рис., 9 табл., 24 джерел.

Метою цього дослідження було визначити вплив восьмитижневого психо-йогічного тренування на вибрані психологічні параметри жінок-новобранців поліції.

Матеріали та методи. Спочатку в дослідженні брали участь 200 жінок-новобранців поліції. 100 учасників 3200 були перевірені за допомогою шкали брехні переглянутого Особистісного опитувальника Айзенка. Потім учасників розділили на дві групи (експериментальну та контрольну) за допомогою методу стратифікованої випадкової вибірки на основі шкали брехні. Психологічними змінними, вибраними для дослідження, були агресія (фізична агресія, вербальна агресія, ворожість і гнів), емоційний інтелект (самосвідомість, управління емоціями, самомотивація, емпатія та соціальні навички), тривожність, суб'єктивний стрес, задоволеність життям і самооцінка. Тести були проведені до і після тренування через вісім тижнів.

Результати. Двосторонній дисперсійний аналіз Фрідмана виявив значну різницю у вербальній агресії $(\mathrm{p}=0,016)$, ворожості $(\mathrm{p}=0,017)$, управлінні емоціями $(\mathrm{p}=0,004)$, самомотивації $(\mathrm{p}=0,004)$, емпатії $(\mathrm{p}=0,017)$, соціальних навичках ( $\mathrm{p}=0,015)$, тривожності $(\mathrm{p}=<0,001)$, суб'єктивному стресі ( $\mathrm{p}=<0,001)$, задоволеності життям $(\mathrm{p}=0,022)$ та самооцінці ( $\mathrm{p}=<0,001)$. Подальший апостеріорний аналіз - тест Краскала Уолліса показав, що експериментальна група значно покращила показники до та після тестування в управлінні емоціями ( $\mathrm{p}=0,005, \mathrm{~d}=0,61, \Delta \%=9)$, самомотивації ( $\mathrm{p}=0,027, \mathrm{~d}=0,57, \Delta \%=8,8)$, соціальних навичках $(\mathrm{p}=0,002, \mathrm{~d}=0,59, \Delta \%=10,2)$, задоволеності життям $(\mathrm{p}=0,036, \mathrm{~d}=0,5, \Delta \%=11,7)$ та самооцінці $(\mathrm{p}=<0,001$, $\mathrm{d}=0,94, \Delta \%=17,6)$. Крім того, в експериментальній групі знизилися тривожність ( $\mathrm{p}=<0,001, \mathrm{~d}=1,27, \Delta \%=59,3) \mathrm{i}$ суб'єктивний стрес ( $\mathrm{p}=<0,001, \mathrm{~d}=1,32, \Delta \%=41,7)$ до та після тестування. 3 іншого боку, контрольна група показала значне зниження фізичної агресії $(\mathrm{p}=0,018, \mathrm{~d}=0,58, \Delta \%$ $=19,9)$, вербальної агресії ( $\mathrm{p}=0,017, \mathrm{~d}=0,57, \Delta \%=17)$ та ворожості ( $\mathrm{p}=0,013, \mathrm{~d}=0,54, \Delta \%=17,8)$.

Висновок. Результати дослідження свідчать про те, що психо-йогічне восьмитижневе тренування $\epsilon$ ефективною стратегією або методом для покращення психологічних параметрів жінок-новобранців поліції.

Ключові слова: емоційний інтелект, тривожність, самооцінка, задоволення, суб'єктивний стрес, агресія.

\section{Information about the authors:}

Singh Tanvi: tanvi.singh@rru.ac.in; https://orcid.org/0000-0001-6195-9707; School of Physical Education and Sports, Rashtriya Raksha University, Gandhinagar, 380305, India.

Kushwah Gaurav Singh: gaurav.kushwah@rru.ac.in; https://orcid.org/0000-0001-6082-8908; School of Physical Education and Sports, Rashtriya Raksha University, Gandhinagar, 380305, India.

Singh Gaurav: gaurav.singh@rru.ac.in; https://orcid.org/0000-0002-6438-1071; School of Physical Education and Sports, Rashtriya Raksha University, Gandhinagar, 380305, India.

Thapa Rohit Kumar: rohitkumar.thapa@rru.ac.in / rohitthapa04@gmail.com; http://orcid.org/0000-0002-1258-9065; School of Physical Education and Sports, Rashtriya Raksha University, Gandhinagar, 380305, India.

Cite this article as: Singh, T., Kushwah, G. S., Singh, G., \& Thapa, R. K. (2021). Effect of Psycho-Yogic Training Intervention on Selected Psychological Variables of Female Police Recruits. Teoriâ ta Metodika Fizičnogo Vihovannâ, 21(4), 330-336. https://doi.org/10.17309/tmfv.2021.4.07

Received: 11.10.2021. Accepted: 29.10.2021. Published: 25.12.2021

This work is licensed under a Creative Commons Attribution 4.0 International License (http://creativecommons.org/licenses/by/4.0). 